\title{
Innovating public participation methods: Technoscientization and reflexive engagement
}

Social Studies of Science 2016, Vol. 46(5) 749-772 (C) The Author(s) 2016

Reprints and permissions: sagepub.co.uk/journalsPermissions.nav DOI: $10.1|77 / 03063| 27 \mid 6641350$

sss.sagepub.com

@SAGE

\author{
Jan-Peter Voß
}

Department of Sociology, Technische Universität Berlin, Berlin, Germany

\author{
Nina Amelung \\ Department of Sociology, Technische Universität Berlin, Berlin, Germany \\ Center for Social Studies (CES), University of Coimbra, Coimbra, Portugal
}

\begin{abstract}
We reconstruct the innovation journey of 'citizen panels', as a family of participation methods, over four decades and across different sites of development and application. A process of aggregation leads from local practices of designing participatory procedures like the citizens jury, planning cell, or consensus conference in the 1970s and 1980s, to the disembedding and proliferation of procedural formats in the $1990 \mathrm{~s}$, and into the trans-local consolidation of participatory practices through laboratory-based expertise since about 2000. Our account highlights a central irony: antitechnocratic engagements with governance gave birth to efforts at establishing technoscientific control over questions of political procedure. But such efforts have been met with various forms of reflexive engagement that draw out implications and turn design questions back into matters of concern. An emerging informal assessment regime for technologies of participation as yet prevents closure on one dominant global design for democracy beyond the state.
\end{abstract}

\section{Keywords}

innovation in governance, citizens jury, consensus conference, planning cell, public participation, technology assessment

\section{Introduction}

Methods of public participation have become an object of study and an issue of concern. Methods such as the citizens jury, planning cell, and consensus conference have been taken up in science and technology studies (STS), not only as a means of fostering public

\footnotetext{
Correspondence:

Jan-Peter Voß, Department of Sociology, Technische Universität Berlin, FH 9-I Fraunhofer Str. 33-36,

Berlin 10587, Germany.

Email: jan-peter.voss@tu-berlin.de
} 
engagement in matters of science and technology, but also as objects of study - as new and emerging fields of science and technology in themselves. Public engagement methods are studied as technologies of participation: as machineries or devices that produce certain versions of the public and perform a particular type of democracy (e.g. Chilvers, 2008; Felt and Fochler, 2010; Gomart and Hajer, 2003; Irwin, 2001; Laurent, 2011; Levidow, 1998; Lezaun and Soneryd, 2007; Rose, 1999; Voß 2016b). As such, they are studied in-the-making, with a view to their social life (cf. Law et al., 2011). A key issue is how the purported neutrality and objective functionality of these devices conceal assumptions about political reality and particular imaginaries of democracy, which are inscribed in the devices by design (Ezrahi, 2012). At first, this inquiry might seem like an extension of the usual concern for ontological politics and collateral realities (Law, 2011; Mol, 1998), applied to another field of technoscience: a new science of politics and democracy that contributes to the development and circulation of technologies of governance and participation. But there are special consequences when a technoscientific mode of world-making is brought to bear on political reality (Voß and Freeman 2016): When political practices and representational procedures become an object of experimentation, to be manipulated and controlled in secluded research (Callon et al., 2009), technoscience is brought to bear on the process of generating political power. If successful, this new science of politics and democracy contributes not only to making specific modes of the articulation of collective wills possible, but also to excluding others. As it is applied to politics and democracy, technoscience thus acts as a lever: the authority and ordering effects of science are multiplied by the authority and ordering effects of the enabled politics (Voß 2016b).

There is a range of case studies on how methods of situated participatory practices are affected by the circulation of planning templates, case reports, skilled bodies, and specific tools. Studies show how publics and democracy are enacted in the practical conduct of participatory procedures (Braun and Schultz, 2010; Gomart and Hajer, 2003; Irwin, 2001), but their results indicate different degrees to which situated participatory practices are preconfigured by trans-locally circulating methods. At one extreme, local settings appear to be largely controlled by coherently articulated methods that effectively prescribe the replication of laboratory-optimized devices (Bogner, 2012; Laurent, 2009; Lezaun and Soneryd, 2007; Ureta, 2015). At the other extreme, case studies describe how methods circulate in bits and pieces, and are flexibly interpreted, recombined, and waywardly appropriated in situated interactions (Dryzek and Tucker, 2008; Felt and Fochler, 2010). Research on the social dynamics of method development also highlights expertization and commercialization, as well as specific innovation cultures among participation professionals (Chilvers, 2008, 2012, 2013; Hendriks and Carson, 2008). Lacking, so far, are studies that follow the development of methods across different sites and over time in order to reconstruct broader patterns of innovation journeys. The aim of this article is to follow the process by which procedural configurations of participatory practices become articulated as abstract functional mechanisms, meant to be technically replicated across regions and issue areas.

We reconstruct the interwoven histories of the citizens jury, planning cell, and consensus conference since the 1970s. Since about 2000, these methods have been subsumed under umbrella terms, like 'citizen panels', 'deliberative forums', or 'mini-publics' (e.g. Brown, 2006; Grönlund et al., 2014; Hörning, 1999). What they have in common is that 
they prescribe procedures for articulating public opinion in small groups of randomly selected ordinary citizens. They foresee the two- to three-day convocations of groups of 10-25 citizens, which deliberate on a consensual judgment on a given issue; the participants are provided with information materials and expert statements and assisted by professional moderators.

Thousands of citizen panels have been conducted on different issue areas and jurisdictions. They serve to generate issue-specific public views, which are drawn on to support or criticize policy programs. As such, they add to or substitute for the 'representative claim' of electoral and parliamentary institutions (Saward, 2006). In contrast to the latter, however, they can be applied beyond the realm of states. For example, they can be applied to legitimate and privately led governance initiatives, scientific and technological development projects, or global governance regimes. Citizen panels appear as a specific form of what Sloterdijk and von der Haegen (2005) ironically advertise as 'instant democracy': The panels offer a mobile and flexible device for generating democratic legitimacy. The format has become a de facto standard of participatory governance (Amelung, 2012) and it is attracting attention as a democratic innovation (Geissel and Newton, 2011; Saward, 2000; Smith, 2009).

We present an account of the innovation journey of citizen panels, based on research that seeks to trace the articulation of citizen panels in formative events across different sites of development and application (for a related approach applied to other instruments of governance, see: Peck and Theodore, 2012; Voß, 2007, 2014, 2016a; Voß and Simons, 2014). We have drawn on academic literature, project documents, personal archives, method manuals, policy reports and websites, as well as transcripts from 30 interviews and a group discussion with 25 actors involved with the development of citizen panel methods. ${ }^{1}$ To reconstruct the pattern of the innovation journey, we began with a repertoire of conceptual propositions on patterns and dynamics, and went through an iterative process of pattern matching and abduction to arrive at a stable interpretation (Van de Ven, 2007: ch. 7; Van de Ven et al., 1999; Yin, 2003).

Our account describes what, to some extent, resembles a process pattern that has been previously described in studies of technological innovation, called 'aggregation' or 'cosmopolitanization' (Geels and Deuten, 2006: 267): 'local knowledge [transforms] into robust knowledge, which is sufficiently general, abstracted and packaged, so that it is no longer tied to specific contexts'. Specific technological designs may thus become established as globally valid, so that they start to orient local practices (Deuten, 2003; Disco et al., 1992). Our account includes important aspects of this pattern: while citizen panels were initially developed as situated practices in specific local contexts, they gradually became decontextualized as methods to be used in various other localities. In the course of this process, the development of procedural designs became laboratorized, and experimental evidence was mobilized to support universal claims of functionality and respective standards. However, the gradual technoscientization of public participation has not led to the establishment of a globally dominant design. It has given rise to different forms of reflexive engagement, which problematize their political implications and repercussions. It appears that the technoscientization of political practices is being dynamically balanced by what can be seen as emerging forms of public assessment for governance technologies. They contribute to keeping the innovation process open, and promote the cultivation of a diversity of approaches to public participation. 
In the following section, we present a case narrative covering four phases. It starts with (1) the situated emergence of practices to organize citizen participation in various localities, then continues via (2) inter-local exchanges and the proliferation of design knowledge across contexts and beyond original actors, and finally ends up with (3) attempts to standardize and consolidate methods of public participation in trans-local centers of expertise. This gives rise to (4) various forms of reflexive engagement, which promote public assessments of their wider repercussions. Following the presentation of the case narrative, we offer a synthesizing discussion of the pattern and its dynamics. In conclusion, we come back to the leverage effect that results from applying the technoscientific mode of ordering to practices of politics and democracy. We discuss the broader dynamics underlying the innovation of citizen panels with regard to how they establish a transnational arena of informal political constitution-building, a trans-local space of remaking democracy.

\section{The innovation journey of citizen panels}

\section{Locally embedded practices of citizen participation}

The innovation journey of citizen panels began in the late 1960s and early 1970s, when participatory practices were procedurally articulated in specific local contexts. During this period, a method called 'the planning cell' emerged in the context of German public infrastructure planning, along with a very similar pattern called 'representative rational and legitimate decision' (later 'the citizens jury') in a context of civic education in the United States. Both developments were supported by active social movements, which problematized technocratic authorities and demanded more participation (Von Alemann, 2011). New methods of participation sought to channel this demand, so that it could productively be linked with established administrative and political decision-making procedures. In this first phase, practices of participation were tightly linked to individuals embedded in local areas of application. The methods gained legitimacy, because those who used them were trusted in terms of motives and competences.

When Peter Dienel developed the planning cell as a new urban development planning procedure in the late 1960s, he drew on his experience and personal connections as a civil servant in the state administration of North-Rhine Westphalia. He proposed to bring together a random group of citizens, provide them with information, let them deliberate on a controversial planning issue, and write up a consensus recommendation for public policy (Dienel, 1970a, 1970b, 1971a, 1971b). Experiments were carried out first with students, and, from 1972, in real world contexts in various cities in the region (Dienel, 1978a): in 1972, three planning cells were conducted as projects of the University of Wuppertal on the subject of rubbish removal, with funding from the Volkswagen Foundation; in 1976, eight planning cells were conducted on regional planning in HagenHaspe. Key design elements, such as the random selection of participants, the payment of an allowance, and the role of facilitators in managing the process, were tested and set in these experiments (Dienel, 1975: 36; 2002: 281). In 1975, Dienel was granted a professorship of sociology at the University of Wuppertal to develop the procedure; this involved setting up a research center (Forschungsstelle Bürgerbeteiligung und Planungsverfahren) and assembling an informal network of researchers, practicing 
facilitators, and supportive public administration officials and politicians (Vergne, 2010). In a book published shortly afterward, Dienel (1978b) presented the planning cell as an experimentally tested participation tool.

At about the same time, a similar procedure for involving small groups of citizens in deliberations on public issues was articulated in the United States. Ned Crosby, a political scientist and philosopher, wrote a $\mathrm{PhD}$ thesis in which he developed a procedure of 'representative rational and legitimate decision', in relation to the problem of civic education. His concern was to empower citizens to counter the dominance of interest groups, professional lobbyists, and think tanks in public discourse (Gastil and Keith, 2005: 14; Vergne, 2010: 3). He drew both on the model of juries in court trials to design spaces for citizens, to deliberate and adjudicate on policy issues such as public health care (Crosby, 1974), and also on more comprehensive policy programs proposed by electoral candidates (Crosby, 1976). In 1974, the Center for New Democratic Processes (later renamed as the 'Jefferson Center') was established as a platform for testing and developing the procedure. Certain elements, such as the selection of participants, the provision of expertise, and the duration of the process were modified until the method was codified under the term 'citizens jury' in 1987 (Vergne, 2010: 3). By 1991, the Jefferson Center had organized twelve citizens juries in Minnesota, all designed and conducted by members of a small network of collaborators.

In the 1980s, the 'consensus conference' took shape as a procedure for getting citizens involved in the assessment of science and technology policy in Denmark. In 1986, the Danish Board of Technology (DBT) was inaugurated as a public body to support the Danish parliament. Its first general secretary, Bo Carstens, presented the consensus conference as a new public engagement approach to technology assessment. Like the planning cell and citizens jury, it was a procedure for assembling small groups of citizens, to let them deliberate on a defined issue on the basis of prepared information. ${ }^{2}$ In its first years, the DBT conducted 22 consensus conferences in Denmark, on issues such as biodiversity, traffic policy, information and communication technologies, and environmental policy (Andersen and Jæger, 1999: 334).

During this phase of the innovation process, the development of participation methods was embedded within separate communities of practice, each rooted within a particular domain of policymaking, specific actor networks, political systems, and culture. Each community was organized around an entrepreneurial figure or public institution, which was equipped with the social capital and authority to draw actors together and mobilize the resources necessary to carry out experiments and generate legitimacy for the particular procedure among participants, target audiences, and wider publics. The approaches were explained by procedural steps and guiding normative principles. The practical knowledge on how to conduct participatory procedures was passed on through on-the-job training and under the supervision of the central figure. The procedures were developed by way of tinkering and bricolage (cf. Garud and Karnoe, 2002), in direct interaction with situational contexts without prior theoretical explanation and planned implementation. Trust in the effectiveness of the procedures emerged through direct interactions within locally embedded networks of participant experts, and through interactions with spokespeople from civil society, academia, politics, and public administration (Vergne, 2010). 


\section{Inter-local exchanges and the proliferation of design knowledge}

From the mid-1980s, the design networks around the planning cell, citizens jury, and consensus conference expanded beyond their original niches. Dedicated demonstration projects were designed to facilitate entry into new issue areas and jurisdictions. Networks of practitioners around the three procedures expanded, community ties loosened, and the procedures became increasingly entangled. The openness and flexibility of the procedural designs facilitated their spread and translation into new contexts, leading to a diversification of participatory practices.

The application areas of planning cells and citizens juries were expanded. The first national showcase for the planning cell was staged in relation to the German energy policy in 1984, in collaboration with Ortwin Renn, then a researcher at Forschungszentrum Jülich, and was supported by Johannes Rau, then state governor of Northrhine Westphalia (Dienel and Renn, 1995: 131; Renn et al., 1993; Vergne, 2010: 6). The first planning cell project outside of Germany was commissioned in 1988, by the Department of Environmental Protection of New Jersey, but the replication of the procedure in a different cultural and political context failed. Participants resisted the prescribed procedure and instead initiated a self-organized process to articulate a statement (Dienel and Renn, 1995: 135). The citizens jury was taken beyond the state of Minnesota, when Crosby and his collaborators joined up with the League of Women Voters in Pennsylvania (1992) and New Jersey (1993). The practice communities around the planning cell and citizens jury came in touch with each other, as they circulated their procedures and expanded into new areas of application. Dienel and Crosby first met in person in 1987, and started to reference each other's work and to act as advisors on the work of each other's centers (Crosby, 1986, 2007).

In 1995, there was the first direct comparison of the planning cell and citizens jury as equivalent models of citizen participation (Renn et al., 1995). In the early 1990s, the Institute of Public Policy Research (IPPR) in the United Kingdom conducted a systematic comparison and produced a compact synthesis of the planning cell and citizens jury approaches, with Ned Crosby and Peter Dienel as consultants. This led to the proposal of a new combined procedure termed as the 'citizens' jury' (Coote and Lenaghan, 1997; Stewart et al., 1994). The IPPR advertised the approach in a media campaign on the British Broadcasting Corporation (BBC) and unleashed hype around citizen panels in the United Kingdom (Chilvers, 2008; Pallett and Chilvers, 2013). The citizens jury was seen as a tool to counter dwindling public trust in science and public administration, in relation to Bovine Spongiform Encephalopathy (BSE) and genetically modified organisms (GMOs) in the second half of the 1990s. It promised to transform public unrest into constructive engagement (Interview \#1):

And the UK government tried as much as they could to push through, to bullet through a pro-GM policy. Eventually it had to agree to concede that public opinion was so heavily stuck against the proposed governmental stance that they had to give in. ... [I]t was coming down from Prime Minister Tony Blair he promised to open up the process, to make it more participatory, to make it more transparent; they specifically promised to use a deliberative participatory process. 
About 500 citizens juries have been conducted since the mid-1990s in the United Kingdom. The wave was supported by the New Labour Government's support for organized citizen participation to build up legitimacy after scandals related with BSE and GMOs. Commissioning bodies included local governments, health authorities, regulatory bodies, the central government, and non-governmental organizations (NGOs) (Joss and Durant, 1995a; Wakeford and Singh, 2008). Upon assuming the office of Prime Minister in 2007, Gordon Brown highlighted citizens' juries as a key tool of a new type of politics (e.g. $B B C$ News, 2007).

New actors met the surge in demand for this service, emerging from beyond the communities around the planning cell, citizens jury, or consensus conference. Market research, opinion polling and consulting companies drew on organizational capacities for event management, focus group research and public relations, and on established service relations with public administration (Interview \#2). The new actors from the consulting sector lacked the socialization and interactive learning experiences that informally bound the pioneers of public participation to certain civic values. Competitive pressures within the surging market meant that democratic ambitions were subordinated to an increased service orientation (Interview \#2):

[I]t was often communications staff rather than policy staff who were often involved in these kinds of work. ... [T] hey were partly about policy and they were partly about how the administration looked. ... [T] hey had a framework of suppliers which Opinion Leader [a market research institute that the authors] and many others were on and it was often the procurement route used for these sorts of exercises for juries forums and so on.

While citizens' juries of a variety of shapes and provenances proliferated in the United Kingdom, the original communities around planning cells, citizens juries, and consensus conferences also sought to ride the wave of public participation. By the second half of the 1990s, all the procedural formats were circulating across regions and issue areas. They were listed in policy reviews and practitioner guides as a set of tools for organizing public participation exercises (Elliott et al., 2005; OECD, 2001). As such, they were used to configure participatory procedures far beyond the issue areas, jurisdictions, and political cultures from which they originated.

The planning cell network produced various spin-offs, which partly competed and partly cooperated in their endeavor to expand into new areas of application in Spain, Switzerland, Austria, the Netherlands, and Japan (Interview \#3). ${ }^{3}$ This produced variations on the original design, such as the 'mini-planning cell' and the 'youth planning cell' (Vergne, 2010: 9).

In 2002, the citizens jury network ran into problems when its organizational stronghold, the Jefferson Center, was threatened with a loss of charity status under US law, and the associated fiscal benefits. To avert the threat, it had to stop doing citizens juries on electoral programs and candidates (Vergne, 2010: 14). But beyond the United States, the Jefferson Center continued to promote citizens juries.

Meanwhile, the consensus conference quickly spread within Europe and beyond, ${ }^{4}$ attracting the particular interest of academics and practitioners of technology assessment. It became a dominant design for public participation in technology assessment by the 
beginning of the 1990s (Joss and Durant, 1995a). A little later, it spread to Australia, North America, and Latin America, and across Asia, with the first applications in Taiwan, South Korea, and Japan (Interview \#4). As it spread, both the label and the procedure were translated to meet local requirements in different contexts of application (Dryzek and Tucker, 2008; Horst and Irwin, 2010; Joss and Durant, 1995b) (Interview \#5). ${ }^{5}$

The proliferation of participatory procedures entailed erosion, both of shared skills and orientations among practitioners, and also of the links with local networks and political cultures from which they had emerged. What started out as local communities of practice, rooted in direct personal interaction, slowly became trans-local communities. In the process, these communities adopted different modes of communication and identity (Amin and Roberts, 2008; Djelic and Quack, 2010). Implicit understandings of the initial purpose and function of citizen panels got lost in this process. Participation procedures were modified and hybridized via methods from marketing and public relations research, such as focus groups and polling (Interview \#13; Lezaun, 2007; Hendriks and Carson, 2008).

Particularly in the UK context, cautionary voices emerged concerning the co-optation of citizen participation to serve governmental agendas. The boom of invited and professionally organized participation in the United Kingdom was said to produce public views using procedures that were not transparent in how they shaped the outcome of participation exercises (Parkinson, 2004, 2006; Wakeford et al., 2007). Moreover, the hybridization of citizen participation with logics and methodologies from marketing and public relations research became an issue of critical academic study (Lezaun, 2007).

Uncertainty increased among the wider public and the commissioners of citizen panels. Journalists, activists, and social scientists started to ask critical questions about the variety of designs and their underlying assumptions (Fung, 2002; Pimbert and Wakeford, 2001; Rowe and Frewer, 2000). Ultimately, the proliferation of citizen-participation methods undermined trust in the procedure, as well as the legitimacy of results. Among participation experts, these developments were problematized as a sign of bad coordination, and later on as an argument for increasing efforts to expertly align and standardize the conduct of public participation exercises (Interview \#5):

You have a whole community of people who have done participation work internationally. ... $[\mathrm{T}]$ he problem isn $t$ that we don $t$ have enough engagement in consultation. The problem is that a lot of it is badly coordinated.

\section{Technoscientific consolidation and trans-local centers of expertise}

Attempts to integrate and coordinate citizen panel practices increased around $2000 .^{6}$ Situated practices were abstractly described and aggregated for systematic surveys, comparisons, and databases, as well as for explanations and evaluations of their effects (Fung, 2006; Rowe and Frewer, 2005). The development of abstract design knowledge started to take shape, as a task separate from the activity of participating in particular situations. A trans-local infrastructure of transnationally active research institutes and service providers, journals, websites, conference series, professional organizations, and networks was established to connect citizen panel practices across the world. As the purpose and function of citizen panels became contested, explicit theoretical models 
were needed to argue for specific descriptors and performance criteria. The task of designing participatory procedure turned into a challenge of developing a technology of participation that could guarantee a function, irrespective of particular issues, political cultures, persons, or other situational circumstances.

The loosening of personal interaction among practitioners and users made it necessary to objectify participatory conduct, so that commissioning bodies and publics could regain trust (cf. Porter, 1996). This required instrumentally reasoned methods. The designs were cleaned up and historical stories and myths were removed. Due to the formal similarities, the planning cell, citizens jury, and consensus conference were bundled together under umbrella terms, like 'citizen panels', 'deliberative forums', or 'minipublics' (Brown, 2006; Goodin and Dryzek, 2006; Hendriks, 2006; Hörning, 1999).

The European Commission played an important role in consolidating sprawling citizen panel practices. From around 2000, it supported projects that served as platforms for the formation of a transnational expert community of citizen participation, mostly with a focus on science and technology, but also with respect to issues like regional development, or the institutional development of the European Union (EU) itself. Projects were funded to organize surveys, compile databases, and conduct comparative evaluations of participatory methods (e.g. IFOK, 2003; PATH, 2004-6: Participatory approaches in Science and Technology; CIPAST, 2005-8: Citizen participation in science and technology). By promoting professional integration and the articulation of general functions, design principles, and standards, the European Commission sought to have flexible but reliable methods at hand for representing the European public, and to counter accusations of a democratic deficit (Interview \#6; European Commission, 2002: 3). Later, the European Commission also funded large-scale experiments to apply citizen panel methods to European policy issues. ${ }^{7}$ Those projects included practitioners, academics, and policy makers who were to negotiate and implement a shared standard. They served as platforms for shaping a trans-local knowledge infrastructure on citizen panels and participation methods, which included the establishment of academic communities, professional associations, and methods training (Interview \#9). ${ }^{8}$

Consolidation and standardization efforts from around 2000 also sought to build up scientific expertise, and to establish authoritative knowledge on the proper design of public participation processes (European Commission, 2009: 35-65). One challenge was to provide a theoretical model to explain how citizen panels functioned, and to demonstrate the replicability of small group deliberations, in order to generate a judgment that can be claimed to be representative for the public as a whole. There was an attempt to meet this challenge by linking citizen panel practices to the theory of deliberative democracy (Brown, 2003; Dryzek, 2000; Fischer, 1999; Smith and Wales, 2002). In effect, the combination of citizen panels with deliberative democracy constituted a technoscientific approach to the design and implementation of participation methods (Bogner, 2012; Laurent, 2009; Sulkin and Simon, 2001). Deliberative democracy provided a model of communicative action that offered generic quality criteria for the design of procedures (Habermas, 1981, 1987). The link provided professional organizers and advocates of citizen panels with a theory (Lövbrand et al., 2011). It gave deliberative democrats a practice field to demonstrate a 'working theory' (Chambers, 2003) and case material for an empirical turn in deliberation research (Carpini et al., 2004). However, such attempts 
did not directly lead to shared understandings and authoritative standards. The process of explaining functions and fixing standards revealed partly contrasting perspectives, and competing ambitions among practitioners of citizen panels (Interview \# 11):

One thing that's interesting about research on citizen panels is that there are really very different scholars from many different disciplines involved, to some extent they're not really talking to each other that much. People much closer to policy analysis, people from democratic theory, as well as empirical political scientists and sociologists ....

The articulation of specific design programs also prompted an articulation of counterprograms. The marriage of public participation methods with Habermas' theory of communicative action was contested by other approaches, which differed in two respects. First, they were less presumptuous about communicative rationality and universal reason (Brown, 2009; Huitema et al., 2007; Wakeford and Singh, 2008) (Group discussion \#1). Second, they mobilized different theories of politics and participation that gave greater weight to situated learning, or to the empowerment of marginalized voices in order to challenge hegemonic discourses (Dewey, 2012 [1954]; Freire, 2000 [1970]; Mouffe, 2000).

Attempts to set standards in the context of European projects and elsewhere thus were rife with struggles over the general purpose, functions, and overall political meaning of citizen panels. Basic ontological differences were seldom explicitly articulated, but they made it difficult to get practitioners of citizen participation to agree on a shared model. ${ }^{9}$ The struggle over standards was linked with different practical traditions, as well as the ambitions of professional service providers to position themselves in a globalizing market.

Even if the trans-local production of design knowledge and atttempts to negotiate standards did not immediately create a shared identity and conceptual framework, it gave rise to denser networks of interaction (Chilvers, 2008; Chilvers and Evans, 2009; Irwin and Michael, 2003). For the dynamics of the innovation journey, this marked a reversal. Inter-local exchanges among embedded practitioners gave rise to a trans-local expert world, with dynamics of its own. Bottom-up processes of tinkering with participation formats, in the context of specific issues and political contexts, complemented top-down processes of producing abstract design knowledge through secluded research (Callon et al., 2009). A division of labour emerged, in which some locales, like transnational expert bodies, EU projects, research institutes, and consultancies took on the task of developing citizen panels as a generic method of participation. Experts in participation came to occupy a central position from which they circulated concepts and tools for configuring participatory practices to other locales (Chilvers, 2008; Laurent, 2009).

The transition served a number of different goals: to enable academics to establish systematic and universal knowledge, and position themselves in a newly emerging research field; to provide politicians with flexible and reliable tools of legitimation; and to make citizen participation a globally standardized services market, for commercial interests. The transition spurred the development of a transnational 'deliberative industry' (Saretzki, 2008: 48-49) - a constituency of citizen panels as a particular instrument of governance. The dynamics of that industry started to shape the roles and identities of 
persons and organizations engaging with the development of participatory methods (cf. Voß and Simons, 2014). This happened not only through functional promises regarding democracy, but also through structural promises regarding positions in a new world of special expertise and services (Interview \#10):

[T] hey want to get credit they want to be recognized they want to have new coins they want to have [an] exclusive brand: trademarks and service marks and so on. ... [F]or those who aren't at the University and not independently wealthy they have to struggle to constantly find new sources of funding. That $\mathrm{s}$ where you see the most problematic behavior. You know they cultivate their clients to such an extent that you worry how truly independent are they? They are committed to deliberation democracy but they also have to sustain themselves.

The self-sustaining dynamics of the emerging constituency led to continuing attempts to demonstrate the effectiveness of citizen panels. Exercises were initiated even before issues had become controversial, particularly in new and largely speculative areas of science and technology or in global politics. Such initiatives represent a form of pre-emptive participation, where the articulation of publics is entirely channeled through the procedure. An example is the DBT's championing of the World Wide Views format. It takes citizen participation to the global governance level, where it promises to provide the views of a global public on issues like global warming or biodiversity (Amelung, 2015). ${ }^{10}$

\section{Reflexive engagement and public assessment of technologies of participation}

However, the move to establish central authority in matters of participatory procedures and the attempts to take questions of function, quality, and design into the laboratory were accompanied by the emergence of new counteracting forces. Various forms of reflexive engagement problematized the shift toward a mode of technoscience for the ordering of participatory practice.

Toward the end of the 1990s, when the trans-local consolidation of design knowledge for citizen panels took off, a reflexive discourse began to problematize the technologizing of democracy (Levidow, 1998) and the establishment of a new class of 'experts of community' who invent, operate, and market devices for eliciting communal values (Rose, 1999: 189). By pointing out the social dynamics and political repercussions of citizen panels, the discourse worked against the objectification of design questions and impeded the technoscientific closure of design questions. A main issue was how particular types of citizens and publics were constructed when these methods were applied (Braun and Schultz, 2010; Gomart and Hajer, 2003; Irwin, 2001; Lezaun and Soneryd, 2007; Wynne, 2006, 2007). However, the political performativity of such methods was concealed by objectifying the design of participation, as a matter of technical functionality and expertise. This was also linked to more fundamental reflections on the artificiality and inevitable bias of any particular procedure for public participation (Gomart and Hajer, 2003), and on the hegemonic tendency of a technological design discourse that turns democratic representation from a matter of concern into a matter of fact. 
In effect, the design of citizen panels became problematized as an emerging technocracy of democratic procedure (Braun and Schultz, 2010). The continuing innovation of participatory methods was challenged by those who claimed that innovation undermined the proclaimed promise to empower citizens vis-à-vis representational institutions and spokespersons of science and government (Bogner, 2012). While it sought to remedy the technocracy of expert-based decision-making on substantial policy issues (e.g. Fischer, 1990), it instead furthered a new technocracy of political procedure, one that sought to define how citizens should assemble, articulate themselves and be regarded as legitimate voices of the public.

Academic discourse was only one type of reflexive engagement. It fueled a more widely felt scepticism about officially organized public participation as a tool to whitewash policies (Wakeford et al., 2007). As such, it also gave rise to the development of alternative citizen panel approaches, such as a do-it-yourself citizens jury to articulate subaltern perspectives and develop activities for engaging with hegemonic public discourses (DIY Jury Steering Group and the Policy Ethics and Life Sciences (PEALS) Research Centre, 2003; Soneryd and Amelung, 2016; Wakeford et al., 2004).

Another type of reflexive engagement was direct protest against the deployment of purportedly neutral technologies of participation. While citizens showed increasing reluctance to participate in organized panel exercises (Maier, 2009), there were also more overt forms of contestation. In 2007, Greenpeace legally challenged public participation procedures on nuclear energy in the UK (Chilvers and Burgess, 2008: 1895). An especially pronounced case of resistance was a campaign against public participation on nanotechnology in France, deliberately orchestrated by the radical protest movement Pièces et Main d'Oeuvre (PMO) (Laurent, 2011). PMO denounced organized participation as a 'parody of public debate' that effectively works to impose a technological rationality on even social and political relations, with the intention of creating a 'machine man in a machine world' (Laurent, 2011: 410, 426). The movement rejected deliberative procedures as 'both a (social) scientific model and a political one'. PMO made several attempts to sabotage the deployment of deliberative procedures: for example, in 2009, they disrupted the orderly conduct of a national public debate on nanotechnology with nonsensical shouting. PMO further sought to link up with other movements for direct action against the deployment of participation technology, in areas like nuclear power and GMOs (Laurent, 2011: 430).

Finally, more formal and constructive approaches of reflexive engagement were also developed. These addressed citizen panels as a technological innovation with potentially problematic dynamics and wider repercussions, which had to be publicly examined and debated, in the same manner that other technologies undergo processes of anticipatory scrutiny and debate. We ourselves organized a workshop inspired by concepts of constructive technology assessment (Rip et al., 1995; Rip and Te Kulve, 2008). In April 2013, with a variety of concerned actors, we delivered this workshop, 'Challenging futures of citizen panels', with the aim to raise critical issues about latent functions and collateral realities (Law, 2011). ${ }^{11}$ That workshop led to an extended innovation agenda, drawing out wider political implications of citizen panel development (Mann et al., 2014). 
Academic discourse, protest action, alternative designs, and constructive assessment exercises may be seen as working together, as emerging forms of 'informal technology assessment' (Rip, 1987) for what is taking shape as a technoscience of political participation. They all have engaged with the ongoing innovation journey, working against a technological black boxing of basic features of political order and democracy. As such, they have become part of the innovation journey and shaped its course. There are signs that the impetus for technoscientific corroboration and standardization of participation methods has been attenuated and complemented by the search for alternative strategies to consolidate rampant and unaccountable practices of performing public participation. The approach is to make underlying political principles and assumptions explicit, as opposed to hiding them in claims of scientific neutrality and universal functionality (Saward, 2003). In contrast with the history of attempts to ensure quality and reliability for citizen panels by seeking to build up a dominant design theory, fact base, and professional standards, there is an emerging understanding that favors more reflexive quality standards. For example, there may be a requirement for organizers of participation to produce a dispatch note, to go along with a 'public view' that results from their exercise. The note would report on the particular purposes and circumstances of the process, with an explicit discussion of the performativity of the method (Mann et al., 2014; Group discussion \#1).

\section{A broader view of innovation dynamics}

Let us briefly recall the basic pattern of the process. We first described a local phase, where novel practices of organizing public participation emerged unconnected, embedded in specific contexts, and shaped by local settings and problem framings. Knowledge of how to participate was largely tacit, for the organizers, commissioners, and wider local communities that were presented with results. This knowledge developed in face-to-face interactions, and did not circulate beyond local and mostly personal networks of communication. A second inter-local phase saw practitioners traveling beyond the contexts in which they developed their methods. They met, exchanged experiences, and started to collaborate. Reports and manuals were also circulated and picked up beyond their contexts of origin. In this way, diverse knowledges of participation produced hybrids. Local communities of practice became loosely coupled and produced offshoots in new areas of application. The booming demand for public participation in the 1990s led new actors from public relations and marketing research to pick up circulating knowledge elements and link them up with their practices. Design knowledge proliferated. Participation exercises were increasingly conducted on the basis of designs that were developed elsewhere, but their knowledge base remained opaque. Conflicts arose between different ways of organizing participation. Commissioners of public participation exercises and the wider public were confronted with alternatives that they were unable to judge and compare. From around 2000, threatened by a loss of trust in organized public participation, the concerned actors made increased efforts to explain functions and quality criteria. This led to a trans-local phase, characterized by systematic reviews of participatory methods, the set-up of case repositories, and the establishment of comparative frameworks, evaluation schemes, quality criteria, and performance standards. Participatory practices were 


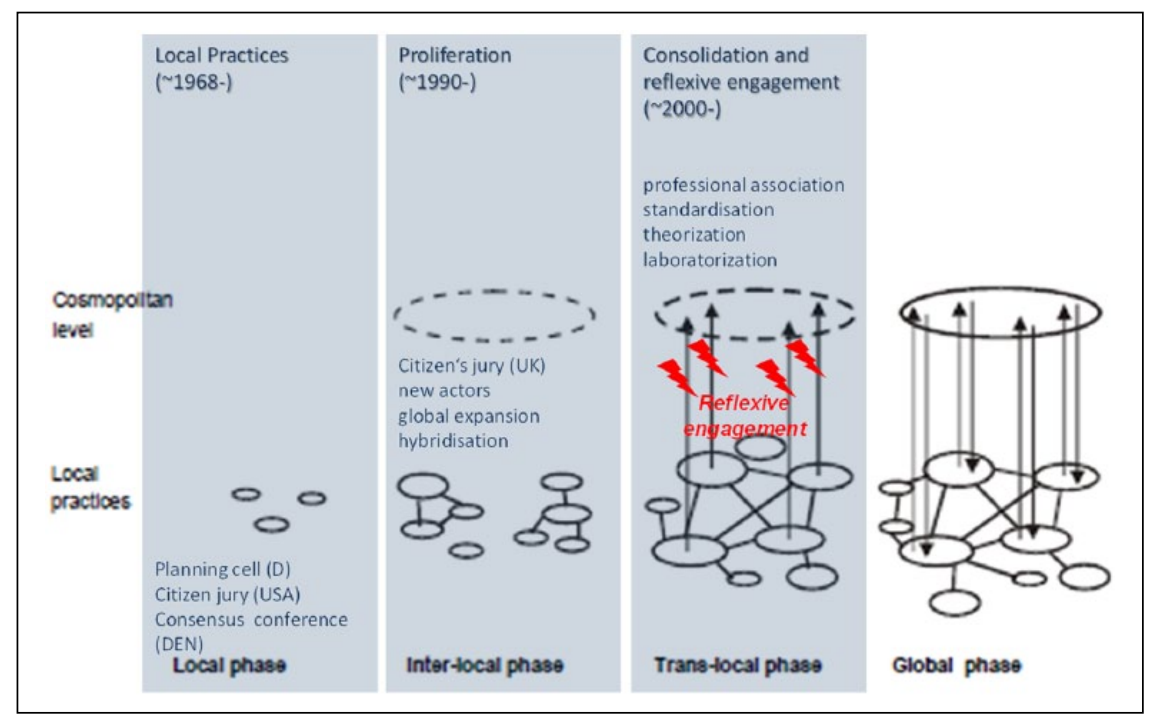

Figure I. The innovation journey of citizen panels as a truncated version of an ideal-typical pattern of aggregation (adaptation of Geels and Deuten, 2006: 269).

both embedded in large international projects and professional associations - an overarching infrastructure for the negotiation of common frameworks - and also linked with generic theories that explained functionality and provided design standards with epistemic authority. Design knowledge became trans-local; it was produced to be generic, mobile, and relevant across different contexts. An important strand sought to establish experimental evidence for theories of deliberative democracy, and to derive universal design standards from it. Trans-local knowledge work was linked with the strengthening of intermediary actors, such as transnational research centers, conference organizers, journal editors, and professional associations. These actors increasingly mediated the knowledge transfer between locally distributed activities, and concentrated the development of abstract design knowledge in emerging centers of trans-local expertise. They started to perceive themselves as part of an emerging community with collective interests in solidifying and expanding certain designs (Geels and Deuten, 2006: 267). Our case drew on a pattern of aggregation that suggests a further transition, from a trans-local to a global phase, where the reversal from inductive generalizations to deductive operationalization is completed, so that a laboratory tested model becomes naturalized and starts to work as a globally dominant design, and collective knowledge repertoires at the global level come to guide local-level activities in an expert-led trajectory, irrespective of the specific situational circumstances (Geels and Deuten, 2006: 268).

In the case of citizen panels, however, we observed that, when prompted by and immediately connected with trans-local knowledge development, reflexive engagement practices emerged. We grouped these practices into a fourth phase, which does not continue the aggregation pattern, but interrupts it and introduces a countervailing dynamic. The effect is that the trajectory is held in tension in a dynamic interplay of technoscientific 
closure and reflexive opening. The pattern may be presented as a truncated version of the aggregation pattern (see Figure 1).

\section{Conclusion}

By following citizen panels along their innovation journey, we asked how methods of participation became articulated, were brought into circulation, and developed as mobile technologies across different sites of development and application.

The innovation journey points to a curious irony of anti-technocratic expertise. The procedures of participation that initially targeted technocratic modes of decision-making gave rise to a new kind of trans-local expertise and attempts to establish epistemic authority in support of certain modes and procedures of public participation. This was again contested as a new technocracy of procedure. A process of technoscientific closure, which sought to establish a globally dominant design, was countered by a critical academic discourse, protest action, alternative procedural designs, and technology assessment exercises. Recent developments point toward the use of more reflexive approaches, which involve justifying participatory designs and outcomes with explicit reference to situational contingencies and performative effects.

We conclude with a discussion of some broader implications. The first point is that there is a specific topology of governance that appears to be linked with technologies of participation: As it circulates, design knowledge connects different sites of development and application and constitutes a trans-local space of governance knowledge within which a particular reality of democracy is practiced. This space cuts across territorial spaces of state authority and transnational discursive spaces constituted by particular issues of public concern. The trans-local development and application of methods of participation seem to take shape as a 'technological network' (Mol and Law, 1994), or a 'technological zone' of democratic practice (Barry, 2001, 2006). We may think of the ordering and expansion of this particular space as a process of cultivating a particular imaginary of democracy (Ezrahi, 2012), and thus as an informal process of constitutional reform on a transnational scale.

The second point is that the design and deployment of participation methods is a special case of ontological politics (Mol, 1998). It is a process of socio-material ordering that configures not just any type of practice, but the practice of doing politics. Establishing knowledge about methods of participation performs a particular reality of democracy. It thereby enables particular ways of generating political authority. Just like any other procedure of political representation, public participation methods help to perform a political translation, the translation of a multitude with a collective interest that obliges to obey norms and partake in collective agency (Latour, 2003). The science and technology of participation therefore works with a leverage effect in terms of the world-making power it generates: It establishes epistemic authority that allows for the generation of political authority. We may think about the science of democracy 'in action' as a form of infrapolitics that sets out elements of the cultural infrastructure of the politics that we perform on a daily basis (Marche, 2012; Voß and Freeman, 2016). Thus, in order to understand innovation in democracy, both on site and at a distance, it seems especially important to turn to the practices of social and political science involved in the design and evaluation of democratic procedure. 


\section{Acknowledgements}

We thank our colleagues in the Innovation in Governance Research Group for stimulating discussions of broader issues related to this article, as well as Brice Laurent, Linda Soneryd, Jason Chilvers, Sonja van der Arend, and Ulrike Felt for comments on an earlier version. Much appreciated are also Sergio Sismondo's editorial suggestions and comments from three anonymous reviewers.

\section{Funding}

The research for this article was funded by the German Federal Ministry for Education and Research (BMBF) under its program of socialecological research, through grant no. $01 \mathrm{UU} 0906$.

\section{Notes}

1. Guided qualitative interviews were conducted with actors involved with the development and conduct of the citizens jury, planning cell, and consensus conference (see Appendix 1). The sample included actors from different regions (Europe, United States, Australia, and Asia) and various issue areas (civic education, planning, and technology assessment), as well as different roles (academic research, policy consultancy, service provision for citizen panels, commissioning of citizen panels, party politics, public administration, and political activism). It also included affirmative and critical perspectives on citizen panels. The interviews centered on respondents' practical engagements with citizen panels, the meanings they attach to them, their views of relations with other actors, and of the developmental dynamics and future challenges of citizen panels.

2. It was developed on the basis of the format of the consensus development conference, which was practiced as an expert-based assessment procedure on health care in the $1980 \mathrm{~s}$ in the United States (Reynolds et al., 2008).

3. The planning cell network produced consultancy offshoots such as Citcon Bonn (1994), Citcon Spain (1995), Nexus (2000), Gesellschaft für Bürgergutachten (2001), and the Akademie für Technikfolgenabschätzung of Baden Württemberg (Interview \#3; Vergne, 2010).

4. Consensus conferences were held in Belgium (1992), The Netherlands (1993), United Kingdom (1994), Norway (1996), Austria (1997), Switzerland (1998), Germany (1998), and France (1998) (Hennen et al., 2004).

5. The method was relabeled to avoid the impression that a predefined consensus would be enforced through the procedure. Thus, for example, it became a citizen panel (United Kingdom), a Burgerforum (The Netherlands), Conference de Citoyen (France), Publiforum (Switzerland), and a Bürgerkonferenz (Germany). Some versions of this method provide for the inclusion of a minority opinion in the final report (Joss and Durant, 1995a).

6. Quality standards sought to avoid outright manipulation of citizen participation by checking on the representative selection of participants, balanced information, and neutral facilitation. They were negotiated among practitioners and scientists (National Coalition for Dialogue and Deliberation (NCDD), 2009). Governments also published guidelines for using professional services of participation (e.g. Austrian Federal Chancellery, 2008; Cabinet Office (UK), 2005; OECD, 2001).

7. One of the first examples of citizen participation on the European level was a 2005 assessment project on brain science, the Meeting of Minds (Abels and Mölders, 2007; Goldschmidt and Renn, 2006). Other demonstration projects followed such as the European Citizen Consultations and the European Citizen Panel (Sellke et al., 2007). Further surveying research 
and standard-building projects such as the New Democratic Toolbox for New Institutions were carried out (European Citizen Action Service (ECAS), 2010).

8. For example, the International Association for Public Participation (www.iap2.org), the International Association of Facilitators (www.iaf-world.org), web-based platforms such as www.participedia.net, www.partizipation.at, and www.peopleandparticipation.net, and dedicated journals such as Public Understanding of Science (since 1992) and the Journal of Public Deliberation (since 2004).

9. Controversial design aspects included the recruitment of participants, criteria of representativeness, the required knowledge for participants, how they should be provided with information materials and expert statements, the format for presenting conclusions, and provisions for assuring policy impact (Interview \#7, Interview \#3, Interview \#8, and group discussion \#1). For an evaluation of the planning cell methodology, see Font and Blanco (2007). For the conduct of experiments in Australia, see Niemeyer (2004) and Jelsoe et al. (2001). For similar undertakings in the Netherlands, see Huitema et al. (2007). For a published controversy on design standards for citizens juries, see Bobbio et al. (2006) and Carson (2006).

10. In 2009, a multi-site deliberation process with citizen panels in 38 countries addressed issues of United Nations (UN) negotiations on climate change. A second process in 2013 addressed UN negotiations on biological diversity (http://www.wwviews.org/).

11. We invited 25 actors (involved with the innovation journey of citizen panels in various different roles, as enactors, users, analysts, critics etc.) to a one-day workshop to discuss dynamics of the innovation process and identify critical issues with regard to future pathways (Voß, 2016b).

\section{Interviews}

Interview \#1: Academic researcher studying consensus conferences Europe 15.06.2012 Interview \#2: Market research professional and organizer of citizens juries Europe 16.05.2012 Interview \#3: Facilitator of planning cells Europe 29.05.2012 Interview \#4: Academic researcher and organizer of consensus conference Asia 09.05.2012 Interview \#5: Applied researcher and consultant specializing in citizen panels Europe 16.05.2012 Interview \#6: Commissioner and funder of research on citizen panels Europe 03.05.2012 Interview \#7: Academic researcher and organizer of citizen panels USA 29.03.2012 Interview \#8: Applied researcher and organizer of planning cells Europe 11.04.2012 Interview \#9: Academic researcher and organizer of citizen panels Australia 03.05.2012 Interview \#10: Academic researcher studying citizens juries USA 04.06.2012 Interview \#11: Academic researcher studying citizen panels USA 16.07.2012 Interview \#12: Advocate of alternative participatory instruments USA 18.05.2012 Interview \#13: Applied researcher and organizer of consensus conferences Europe 27.03.2012 Group discussion \#1: Workshop with 25 actors 26 April, 2013 Berlin (Mann et al., 2014)

\section{References}

Abels G and Mölders M (2007) Meeting of minds. Kritische Beobachtungen zu Form und Funktion der ersten europäischen Bürgerkonferenz. In: Bora A, Bröchler S and Decker M (eds) Technology Assessment in der Weltgesellschaft. Berlin: Sigma, pp. 381-391.

Amelung N (2012) The emergence of citizen panels as a de facto standard. Quaderni 79: 13-28.

Amelung N (2015) Standardizing heterogeneity: Negotiating designs for transnational citizen engagement. In: Rask M and Worthington R (eds) Governing Biodiversity through Democratic Deliberation. London and New York: Routledge, pp. 249-268.

Amin A and Roberts J (2008) Knowing in action: Beyond communities of practice. Research Policy 37(2): 353-369. 
Andersen I and Jæger B (1999) Scenario workshops and consensus conferences: Towards more democratic decision-making. Science and Public Policy 26(5): 331-340.

Austrian Federal Chancellery (2008) Standards of public participation. Available at: http://www. partizipation.at/fileadmin/media_data/Downloads/Standards_OeB/oebs_standards_engl_ finale_web.pdf (accessed 30 March 2015).

Barry A (2001) Political Machines: Governing a Technological Society. London: Athlone Press.

Barry A (2006) Technological zones. European Journal of Social Theory 9(2): 239-253.

$B B C$ News (2007) Brown defends new citizen juries. BBC News, 6 September. Available at: http:// news.bbc.co.uk/2/hi/uk_news/politics/6980747.stm (accessed 8 October 2010).

Bobbio L, Lewanski R, Romano I, et al. (2006) Five responses to Carson on citizen juries in Italy. Journal of Public Deliberation 2(1): Article 11.

Bogner A (2012) The paradox of participation experiments. Science, Technology \& Human Values 37(5): 506-527.

Braun K and Schultz S (2010) '... a certain amount of engineering involved': Constructing the public in participatory governance arrangements. Public Understanding of Science 19(4): $403-419$.

Brown MB (2003) Wie kommt die Gesellschaft in die Wissenschaft. Gegenworte 11: 55-57.

Brown MB (2006) Survey article: Citizen panels and the concept of representation. The Journal of Political Philosophy 14(2): 203-225.

Brown MB (2009) Science in Democracy: Expertise, Institutions and Representation. Cambridge, MA: MIT Press.

Cabinet Office (UK) (2005) Cabinet code of practice on consultation: Better regulation executive. Available at: http://www.partizipation.at/fileadmin/media_data/Downloads/Standards_OeB/ UK_Code_of_Pract_Consult_2004.pdf (accessed 30 March 2015).

Callon M, Lascoumes P and Barthe Y (2009) Acting in an Uncertain World: An Essay on Technical Democracy. Cambridge, MA: MIT Press.

Carpini M, Delli X, Cook F, et al. (2004) Public deliberation, discursive participation and citizen engagement: A review of the empirical literature. Annual Review of Political Science 7: 315-344.

Carson L (2006) Improving public deliberative practice: A comparative analysis of two Italian citizens jury projects. Journal of Public Deliberation 2(1): Article 12.

Chambers S (2003) Deliberative democratic theory. Annual Review of Political Science 6(1): $307-326$.

Chilvers J (2008) Environmental risk uncertainty and participation: Mapping an emergent epistemic community. Environment and Planning A 40(12): 2990-3008.

Chilvers J (2012) Expertise technologies and ecologies of participation. 3S Working paper. Norwich: Science Society and Sustainability Research Group, University of East Anglia.

Chilvers J (2013) Reflexive engagement? Actors learning and reflexivity in public dialogue on science and technology. Science Communication 35(3): 283-310.

Chilvers J and Burgess J (2008) Power relations: The politics of risk and procedure in nuclear waste governance. Environment and planning A 40(8): 1881-1900.

Chilvers J and Evans J (2009) Understanding networks at the science-policy interface. Geoforum 40(3): 355-362.

Coote A and Lenaghan J (1997) Citizens Jury: Theory into Practice. London: Institute for Public Policy Research.

Crosby N (1974) The Educated Random Sample. A Pilot Study on a New Way to Get Citizen Input into the Policy-Making Process. Saint Paul, MN: The Center for New Democratic Processes.

Crosby N (1976) Policy jury on 1976 presidential elections: Summary of results and conclusions. Available at: http://www.jefferson-center.org/vertical/Sites/\%7BC73573A1-16DF-4030-99A5- 
8FCCA2F0BFED\%7D/uploads/\%7BE80DF3A5-080B-40F8-8A04-67F1AEE0809E\%7D. PDF (accessed 30 March 2015).

Crosby N (1986) Preliminary report: Citizen panel on transplants and public policy. Available at: http://jefferson-center.org/wp-content/uploads/2012/10/Organ-Transplants.pdf (accessed 30 March 2015).

Crosby N (2007) Peter C. Dienel: Eulogy for a deliberative democracy pioneer. Journal of Public Deliberation 3(1): Article 7.

Deuten JJ (2003) Cosmopolitanising Technologies: A Study of Four Emerging Technological Regimes. Enschede: Twente University Press.

Dewey J (2012 [1954]) The Public and its Problems: An Essay in Political Inquiry. University Park, PA: Penn State University Press.

Dienel P (1970a) Partizipation an Planungsprozessen. Raumforschung und Raumordnung 5: 70.

Dienel P (1970b) Techniken bürgerschaftlicher Beteiligung an Planungsprozessen. In: von Pufendorf U (ed.) Partizipation: Aspekte politischer Kultur. Geistige und strukturelle Bedingungen. Modelle und Partizipationsformen. Wiesbaden: Westdeutscher Verlag, pp. 144-156.

Dienel P (1971a) Partizipation an Planungsprozessen als Aufgabe der Verwaltung. Die Verwaltung 4(1): 151-176.

Dienel P (1971b) Wie können die Bürger an Planungsprozessen beteiligt werden? Planwahl und Planungszelle als Beteiligungsverfahren. Der Bürger im Staat 21(3): 151-156.

Dienel P (1975) Zur Entwicklung eines Verfahrens geordneter bürgerschaftlicher Planungsbeteiligung. In: Zur Strategie der Partizipationsausweitung, Panel at the Conference of the German Association of Political Science, 7-10 October, Duisburg: DVPW.

Dienel P (1978a) Bürger planen Hagen-Haspe: Die Testläufe der, Planungszelle. Dortmund: Institut für Landes-und Stadtentwicklungsforschung des Landes Nordrhein-Westfalen (ILS).

Dienel P (1978b) Die Planungszelle: Eine Alternative zur Establishment-Demokratie. Opladen: Westdeutscher Verlag.

Dienel P (2002) Die Planungszelle: Der Bürger als Chance. Wiesbaden: Westdeutscher Verlag.

Dienel P and Renn O (1995) Planning cells: A gate to fractal mediation. In: Renn O, Webler T and Wiedemann PM (eds) Fairness and Competence in Citizen Participation: Evaluating Models for Environmental Discourse. Dordrecht: Kluwer, pp. 117-140.

Disco C, Rip A and van der Meulen B (1992) Technical innovation and the universities: Divisions of labour in cosmopolitan technical regimes. Social Science Information 31(3): 465-507.

DIY Jury Steering Group and the Policy Ethics and Life Sciences (PEALS) Research Centre (2003) Do-It-Yourself Citizens Jury: Newcastle upon Tyne Jury Verdict. Newcastle upon Tyne: Policy Ethics and Life Sciences Research Centre, Newcastle University.

Djelic M and Quack S (2010) Transnational communities and governance. In: Djelic M and Quack S (eds) Transnational Communities: Shaping Global Economic Governance. Cambridge: Cambridge University Press, pp. 3-36.

Dryzek JS (2000) Deliberative Democracy and Beyond: Liberals, Critics, Contestations. Oxford: Oxford University Press.

Dryzek JS and Tucker A (2008) Deliberative innovation to different effect: Consensus conferences in Demark France and the United States. Public Administration Review 68: 864-876.

Elliott J, Heesterbeek S, Lukensmeyer CJ, et al. (2005) Participatory Methods Toolkit: A Practitioners Manual. Brussels: King Baudouin Foundation and Flemish Institute for Science and Technology Assessment. 
European Citizen Action Service (ECAS) (2010) How the participatory toolbox can make the European Union less remote from citizens. Available at: http://www.communicate-europe. co.uk/fileadmin/files_emi/ECAS_Summary_European_Citizens_Panel_Project.pdf (accessed 27 April 2015).

European Commission (2002) Towards a Reinforced Culture of Consultation and Dialogue General Principles and Minimum Standards for Consultation of Interested Parties by the Commission. Brussels: Commission of the European Communities.

European Commission (2009) Challenging futures of science in society - Emerging trends and cutting-edge issues. Report of the MASIS Expert Group set up by the European Commission. Luxembourg: Commission of the European Communities. Available at http://www.securepart. eu/download/com-2009_masis_report_expert-group-_en150625092421.pdf (accessed 2 March 2016).

Ezrahi Y (2012) Imagined Democracies: Necessary Political Fictions. Cambridge: Cambridge University Press.

Felt U and Fochler M (2010) Machineries for making publics: Inscribing and de-scribing publics in public engagement. Minerva 48(3): 319-338.

Fischer F (1990) Technocracy and the Politics of Expertise. Newbury Park, CA: Sage.

Fischer F (1999) Technological deliberation in a democratic society: The case for participatory inquiry. Science and Public Policy 26(5): 294-302.

Font J and Blanco I (2007) Procedural legitimacy and political trust: The case of citizen juries in Spain. European Journal of Political Research 46(4): 557-589.

Freire P (2000 [1970]) Pedagogy of the Oppressed. New York: Continuum International Publishing Group.

Fung A (2002) Collaboration and countervailing power: Making participatory governance work. In: Annual meeting, Chicago, IL, 16-19 August. Washington, DC: American Sociological Association.

Fung A (2006) Varieties of participation in complex governance. Public Administration Review 66(S1): 66-75.

Garud R and Karnoe P (2002) Bricolage versus breakthrough: Distributed and embedded agency in technology entrepreneurship. Research Policy 32(2): 227-300.

Gastil J and Keith WM (2005) A nation that (sometimes) likes to talk: A brief history of public deliberation in the United States. In: Gastil J and Levine P (eds) The Deliberative Democracy Handbook. Strategies for Effective Civic Engagement in the 21st Century. San Francisco, CA: Jossey-Bass, pp. 3-19.

Geels F and Deuten JJ (2006) Local and global dynamics in technological development: A sociocognitive perspective on knowledge flows and lessons from reinforced concrete. Science and Public Policy 33(4): 265-275.

Geissel B and Newton K (2011) Evaluating Democratic Innovations: Curing the Democratic Malaise? London: Routledge.

Goldschmidt R and Renn O (2006) Meeting of Minds - European Citizens Deliberation on Brain Sciences. Final Report of the External Evaluation. Stuttgart: Dialogik GmbH.

Gomart E and Hajer MA (2003) Is that politics? For an inquiry into forms in contemporary politics. In: Joerges B and Nowotny H (eds) Social Studies of Science and Technology: Looking Back Ahead. Dordrecht: Kluwer, pp. 33-61.

Goodin RE and Dryzek JS (2006) Deliberative impacts: The macro-political uptake of mini-publics. Politics and Society 34(2): 219-244.

Grönlund K, Bächtiger A and Setälä M (2014) Deliberative Mini-Publics: Involving Citizens in the Democratic Process. Colchester: ECPR Press. 
Habermas J (1981) Theorie des Kommunikativen Handelns. Handungsrationalität und Gesellschaftliche Rationalisierung. Frankfurt am Main: Suhrkamp.

Habermas J (1987) Moralbewusstsein und Kommunikatives Handeln. Frankfurt am Main: Suhrkamp.

Hendriks CM (2006) When the forum meets interest politics: Strategic uses of public deliberation. Politics and Society 34(4): 571-602.

Hendriks CM and Carson L (2008) Can the market help the forum? Negotiating the commercialization of deliberative democracy. Policy Sciences 41(4): 293-313.

Hennen L, Petermann T and Scherz C (2004) Partizipative Verfahren der Technikfolgenabschätzung und parlamentarische Politikberatung: Neue Formen der Kommunikation zwischen Wissenschaft Politik und Öffentlichkeit. Berlin: Büro für Technikfolgenabschätzung beim deutschen Bundestag (TAB).

Hörning G (1999) Citizens panels as a form of deliberative technology assessment. Science and Public Policy 26(5): 351-359.

Horst M and Irwin A (2010) Nations at ease with radical knowledge: On consensus consensusing and false consenusness. Social Studies of Science 40(1): 105-126.

Huitema D, van de Kerkhof M and Pesch U (2007) The nature of the beast: Are citizens juries deliberative or pluralist? Policy Sciences 40(4): 287-311.

IFOK (2003) Governance of the European Research Area: The Role of Civil Society. Bensheim: Institut für Organisationskommunikation.

Irwin A (2001) Constructing the scientific citizen: Science and democracy in the biosciences. Public Understanding of Science 10(1): 1-18.

Irwin A and Michael M (2003) Science Social Theory and Public Knowledge. Maidenhead: Open University Press.

Jelsøe E, Einsiedel E and Breck T (2001) Publics at the technology table. The consensus conference in Denmark, Canada, and Australia. Public Understanding of Science 10(1): 83-98.

Joss S and Durant J (1995a) Public Participation in Science: The Role of Consensus Conferences in Europe. London: Science Museum.

Joss S and Durant J (1995b) The UK national consensus conference on plant biotechnology. Public Understanding of Science 4(2): 195-204.

Latour B (2003) What if we talked politics a little? Contemporary Political Theory 2(2): 143-164.

Laurent B (2009) Replicating participatory devices: The consensus conference confronts nanotechnology. CSI Working paper series 2009(018). Paris: Center for the Sociology of Innovation.

Laurent B (2011) Democracies on trial: Assembling nanotechnology and its problems. PhD Thesis, École des Mines, Paris.

Law J (2011) Collateral realities. In: Rubio FD and Baert P (eds) The Politics of Knowledge. London: Routledge, pp. 156-178.

Law J, Ruppert E and Savage M (2011) The double social life of method. CRESC Working paper series. Milton Keynes: Center for Research on Socio-Cultural Change, Open University.

Levidow L (1998) Democratizing technology - Or technologizing democracy? Regulating agricultural biotechnology in Europe. Technology in Society 20(2): 211-226.

Lezaun J (2007) A market of opinions: The political epistemology of focus groups. The Sociological Review 55: 130-151.

Lezaun J and Soneryd L (2007) Consulting citizens: Technologies of elicitation and the mobility of publics. Public Understanding of Science 16(3): 279-297.

Lövbrand E, Pielke R and Beck S (2011) A democracy paradox in studies of science and technology. Science, Technology \& Human Values 36(4): 474-496. 
Maier J (2009) Nanotechnologie: Warten auf den Störfall. Die Zeit, no. 27, 25 June. Available at: http://www.zeit.de/2009/27/N-Nano

Mann C, Voß J, Amelung N, et al. (2014) Challenging futures of citizen panels. Critical issues for robust forms of public participation. A report based on interactive anticipatory assessment of the dynamics of governance instruments. Berlin: Technische Universität Berlin.

Marche G (2012) Why infrapolitics matters. Revue française d'Études Américaines 1: $3-18$.

Mol A (1998) Ontological politics: A word and some questions. The Sociological Review 46(S): 74-89.

Mol A and Law J (1994) Regions networks and fluids: Anaemia and social topology. Social Studies of Science 24(4): 641-671.

Mouffe C (2000) The Democratic Paradox. London: Verso.

National Coalition for Dialogue and Deliberation (NCDD) (2009) Core principles for public engagement. Available at: http://ncdd.org/rc/wp-content/uploads/2010/08/PEPfinalexpanded.pdf (accessed 27 April 2015).

Niemeyer S (2004) Deliberation in the wilderness: Displacing symbolic politics. Environmental Politics 13(2): 347-372.

OECD (2001) Citizens as Partners: OECD Handbook on Information Consultation and Public Participation in Policy-Making. Paris: OECD.

Pallett H and Chilvers J (2013) A decade of learning about publics participation and climate change: Institutionalising reflexivity? Environment and Planning A 45(5): 1162-1183.

Parkinson J (2004) Why deliberate? The encounter between deliberation and new public managers. Public Administration 82(2): 377-395.

Parkinson J (2006) Deliberating in the Real World: Problems of Legitimacy in Deliberative Democracy. Oxford: Oxford University Press.

Peck J and Theodore N (2012) Follow the policy: A distended case approach. Environment and Planning A 44(1): 21-30.

Pimbert M and Wakeford T (2001) Overview: Deliberative democracy and citizen empowerment. PLA Notes 40: 23-28.

Porter TM (1996) Trust in Numbers: The Pursuit of Objectivity in Science and Public Life. Princeton, NJ: Princeton University Press.

Renn O, Webler T and Wiedemann P (1995) Fairness and Competence in Citizen Participation: Evaluating Models for Environmental Discourse. Dordrecht: Kluwer.

Renn O, Webler T, Rakel H, et al. (1993) Public participation in decision-making: A three-step procedure. Policy Sciences 26(3): 189-214.

Reynolds L, Soneryd L and Szerszynski B (2008) Risk deliberation. European Commission Community Research, CARGO - Comparison of Approaches to Risk Governance, Contract Number: FP6-036720. Available at: http://www.cargoproject.eu/docs/project-deliverables/ wp3_risk_deliberation.pdf

Rip A (1987) Controversies as informal technology assessment. Knowledge: Creation Diffusion Utilization 8(2): 349-371.

Rip A and Te Kulve H (2008) Constructive technology assessment and socio-technical scenarios. In: Fisher E, Selin C and Wetmore J (eds) The Yearbook of Nanotechnology in Society, Vol. I: Presenting Futures. Heidelberg: Springer, pp. 49-70.

Rip A, Misa TJ and Schot JP (1995) Managing Technology in Society. The Approach of Constructive Technology Assessment. London: Pinter.

Rose NS (1999) Powers of Freedom: Reframing Political Thought. Cambridge: Cambridge University Press. 
Rowe G and Frewer LJ (2000) Public participation methods: A framework for evaluation. Science, Technology \& Human Values 25(1): 3-29.

Rowe G and Frewer LJ (2005) A typology of public engagement mechanisms. Science, Technology \& Human Values 30(2): 251-290.

Saretzki T (2008) Policy-Analyse, Demokratie und Deliberation. Theorieentwicklung und Forschungsperspektiven der "Policy Sciences of Democracy" In: Janning F and Toens K (eds) Die Zukunft der Policy-Forschung. Theorien, Methoden, Anwendungen. Wiesbaden: VS Verlag für Sozialwissenschaften, pp. 34-54.

Saward M (2000) Democratic Innovation: Deliberation Representation and Association. London: Routledge.

Saward M (2003) Enacting democracy. Political Studies 51(1): 161-179.

Saward M (2006) The representative claim. Contemporary Political Theory 5(3): 297-318.

Sellke P, Renn O and Cornelisse C (2007) European Citizens Panel. Final Report of the External Evaluation (Stuttgarter Beiträge zur Risiko- und Nachhaltigkeitsforschung). Stuttgart: Universität Stuttgart.

Sloterdijk P and von der Haegen G (2005) Instant democracy: The Pneumatic Parliament ${ }^{\circ}$. In: Latour B and Weibel P (eds) Making Things Public: Atmospheres of Democracy. Cambridge, MA: MIT Press, pp. 952-955.

Smith G (2009) Democratic Innovations: Designing Institutions for Citizen Participation. Cambridge: Cambridge University Press.

Smith G and Wales C (2002) Citizens juries' and deliberative democracy. Political Studies 48(1): $51-65$.

Soneryd L and Amelung N (2016) Translating participation: Scenario workshops and citizens' juries across situations and contexts. In: Voß J and Freeman R (eds) Knowing Governance: The Epistemic Construction of Political Order. Basingstoke: Palgrave Macmillan, pp. 155-174.

Stewart J, Kendall E and Coote A (1994) Citizens' Juries. London: Institute for Public Policy Research.

Sulkin T and Simon AF (2001) Habermas in the lab: A study of deliberation in an experimental setting. Political Psychology 22(4): 809-826.

Ureta S (2015) A failed platform: The citizen consensus conference travels to Chile. Public Understanding of Science. Epub ahead of print 7 January. DOI: 10.1177/0963662514561940.

Van de Ven AH (2007) Engaged Scholarship: A Guide for Organizational and Social Research: A Guide for Organizational and Social Research. Oxford: Oxford University Press.

Van de Ven AH, Polley D, Garud R, et al. (1999) The Innovation Journey. Oxford: Oxford University Press.

Vergne A (2010) Das Modell Planungszelle - Citizens Juries: Diffusion einer Politischen Innovation. Unpublished manuscript.

Von Alemann U (2011) 40 Jahre Bürgerbeteiligung-Demokratie als Wagnis. In: Beck K and Ziekow J (eds) Mehr Bürgerbeteiligung Wagen. Wege zur Vitalisierung der Demokratie. Wiesbaden: VS Verlag, pp. 201-212.

Voß J (2007) Designs on governance: Development of policy instruments and dynamics in governance. $\mathrm{PhD}$ Thesis, University of Twente, Enschede. Available at: http://doc.utwente. nl/58085/1/thesis_Voss.pdf (accessed 2 March 2016).

Voß J (2014) Performative policy studies: Realizing, transition management. Innovation - The European Journal of Social Science Research 27(4): 317-343.

Voß J (2016a) Realizing instruments: performativity in emisions trading and citizen panels. In: Voß J and Freeman R (eds) Knowing Governance: The Epistemic Construction of Political Order. Basingstoke: Palgrave Macmillan, pp. 127-154. 
Voß J (2016b) Reflexively engaging with technologies of participation: Constructive assessment for public participation methods. In: Chilvers J and Kearnes MB (eds) Remaking Participation: Science, Environment and Emergent Publics. London: Routledge, pp. 238-260.

Voß J and Freeman R (2016) Introduction: Knowing governance. In: Voß J and Freeman R (eds) Knowing Governance: The Epistemic Construction of Political Order. Basingstoke: Palgrave Macmillan, pp. 1-33.

Voß J and Simons A (2014) Instrument constituencies and the supply-side of policy innovation: The social life of emissions trading. Environmental Politics 23(5): 735-754.

Wakeford T and Singh J (2008) Towards empowered participation: Stories and reflections. Participatory Learning and Action 58: 6-10.

Wakeford T, Murtuja B and Bryant P (2004) Using democratic spaces to promote social justice in northern towns. Newcastle upon Tyne: Institute of Policy and Practice, Newcastle University.

Wakeford T, Singh J, Murtuja B, et al. (2007) The jury is out: How far can participatory projects go towards reclaiming democracy? In: Reason $\mathrm{P}$ and Bradbury $\mathrm{H}$ (eds) The SAGE Handbook of Action Research: Participative Inquiry and Practice. London: SAGE, pp. 333-349.

Wynne B (2006) Public engagement as a means of restoring public trust in science - Hitting the notes but missing the music? Public Health Genomics 9(3): 211-220.

Wynne B (2007) Public participation in science and technology: Performing and obscuring a political-conceptual category mistake. East Asian Science Technology and Society 1(1): 99-110.

Yin RK (2003) Case Study Research: Design and Methods. Thousand Oaks, CA: SAGE.

\section{Author biographies}

Jan-Peter Voß is Juniorprofessor of Sociology of Politics at Technische Universität Berlin. His current research is on relations of epistemic and political authority in the making of collective order, looking particularly at the historical emergence, development, and expansion of new forms of governance and democracy. He is co-editor of 'Knowing governance. The epistemic construction of political order' (with Richard Freeman, Palgrave 2016).

Nina Amelung, sociologist, works as a $\mathrm{PhD}$ candidate at Technische Universität Berlin on her thesis 'Democracy Under Construction: The Micropolitics of Coordinating Transnational Public Engagement'. She is a research associate in the project 'Exchange' at the University of Coimbra, funded by the European Research Council. Her research comprises the social construction of citizenship, the public, and democracy in transnational contexts. 